\title{
The impact of COVID-19 pandemic on logistics firms in Vietnam
}

\author{
Minh Ngoc Do \\ Business Faculty - FPT University \\ ngocdm@fpt.edu.vn
}

\author{
Nguyen Thi Dung, Tran The Tuan. \\ University of Transport Technology \\ \{dungnt, tuantt83\}@utt.edu.vn
}

\begin{abstract}
The paper examines the impact of Coronavirus epidemic on logistics companies in Vietnam and firm responses. Results show that most firms are negatively affected by the pandemic, micro and small businesses are hit the hardest. Coping strategies of firms often involve COVID-prevention practices as required by the government with little investment on technological application and human resource development. Analysis concludes that Vietnamese logistics companies are not well-prepared for crises, especially firms of small sizes which partly show resistance to new digitalizing practices despite the current circumstances brought on by the pandemic.
\end{abstract}

Index Terms-logistics company, supply chain disruption, COVID-19 pandemic, crisis response

\section{INTRODUCTION}

$\mathrm{T}$ HE ROLE of logistics and transportation firms in a supply chain involves moving, storing, and managing flow of goods through different channels. The COVID-19 pandemic has caused a severe disruption and makes it challenging for those firms to fulfill their role. In identifying logistics-relevant disasters, there are five external factors that affect logistics operations: infrastructure (such as port capacity or congestions), physical (such as poor weather conditions), socio-economic factors, government factors, and security factors (such as maritime piracy) [8]; these five factors are interconnected and exert a holistic impact on logistics activities. Similarly, the case of COVID-19 pandemic poses challenges to businesses due to a combination of different factors. Corona virus in the physical environment affects socioeconomic factors regarding consumer behaviors [7], crossborder supply - demand [1], and business' supply chain management along with means of trade [8]. Policymakers are confronted with challenges in health care and unemployment, and in designing interventions to prevent economic shutdowns. Firms have to adapt to different situations mandated by the government (such as border close or temporary operation shutdowns) amidst the operational and financial struggles. Reduced opportunities for trade cause a strain on the performance of logistics and transportation companies. Many companies have to mitigate risks by diversifying their modes of logistics and transport such as warehousing, handling inventory, or freight forwarding [9]. In general, there is a lack of research on Vietnamese context despite the importance of logistics to economic development and the challenges logistics companies are encountering. There is also a scarcity of papers investigating logistics firms in COVID-19 pandemic. To contribute to understanding of how this global event have an impact on logistics companies, this paper will inspect the influence of the pandemic on Vietnamese logistics companies and how they respond to difficulties caused by the pandemic.

\section{Literature Review}

\section{A. COVID-19 pandemic and global supply chain}

The global interrelationship between firms, nations, and production networks has not always been in good situations in the last few decades. For example, the 2007/2008 financial breakdown that had an everlasting impact globally can be considered as a disastrous situation. The COVID-19 event can also be viewed as such a situation, but on a greater scale regarding its effect on the global supply chain and international trade. Publication by the World Trade Organization shows that COVID-19 pandemic caused an eleven-percentdecline in world merchandise trade for nearly the whole year of 2020 [14]. While this number is comparable to the decline caused by the $2007 / 2008$ financial crisis, consequences caused by COVID-19 are more economically serious because foreign direct investment is hit the hardest - a key indicator of international production. Many investment plans are either deferred or blocked, greenfield projects are postponed, mergers and acquisitions are either cancelled or put on hold. The $\mathrm{UN}$ reported of the collapse of global foreign direct investment in 2020 , reducing by $42 \%$ [12]. To put it simply, the corona virus has caused unprecedented global economic crisis, and global supply chain are at the heart of the crisis. Many claim that containment methods are the main reason for disruptions in the supply/value chain [3]. Regardless of domestic containment measures, purely external shocks (such as lockdown in other countries) explain for one third of overall reduction in gross domestic product of every country in total 64 examined countries across six continents [4]. Besides, the COVID-19 pandemic causes a demand shock, because businesses and individuals are cautious with purchases [2].

\section{B. Impact of COVID-19 in Vietnamese context}

The first cases of corona virus contraction in Vietnam were recorded in January 2020, the country quickly imposed containment measures such as tightening border control, visa restrictions, self-isolation, or compulsory quarantine [11]. The pandemic shock significantly deteriorates corporate profitability; real GDP growth of the country was reduced in the beginning of 2020 amid rising global uncertainties. Among the interest coverage ratio (ICR) across Vietnamese firms of different sectors to evaluate risk exposure caused by COVID-19, transportation has the highest risk. Before the pandemic, the cross-border trade of Vietnam had an average annual increase of at least $14-15 \%$, resulting in a corresponding growth of logistics sector. However, since the beginning of 2020, the demand for logistics services has been significantly reduced. Trade activities between Vietnam and neigh- 
boring countries (such as China, Laos, and Cambodia) have been congested; imports are reduced; orders from the US and Europe decrease, all of which negatively affect the manufacturing sector, logistics operation and transportation services [5]. The survey by Vietnam Logistics Association (VLA) shows that $20-50 \%$ of company members record declined revenues, where aviation, road and railway logistics are affected the most, especially during social isolation periods [13]. $80 \%$ of the members in VLA are small and medium businesses and suffer the most; many have to delay production; some even are at risks of closing if the pandemic prolongs. In the circumstances of changes brought on by the pandemic, the role of technology in enhancing performance and reducing risks is underlined more clearly. The industrial revolution 4.0 has transformed warehousing and distribution activities around the world. Logistics companies rapidly integrate technology in their operation by using modern and automated equipment to increase profitability and enhance operational effectiveness. However, most Vietnamese logistics firms are small and medium; and thus, are constrained in terms of capital, labor and technology [10] in order to get on that path. Furthermore, poor synchronous linkage between different stages of logistics activities makes it challenging for firms to satisfy customers in terms of cost [13]. Another common issue that affects the E-logistics transformation of businesses is poor quality of human resources in logistics companies; up to $95 \%$ of workers are not trained in logistics [13], and even more lack necessary technical skills.

This paper intends to identify the impact of Coronavirus pandemic on Vietnamese logistics companies and their responses, specifically examining firms' technological application in coping with difficulties brought on by the pandemic. The paper adopts the quantitative approach to facilitate a descriptive and analytic examination. A questionnaire was issued online in 2021 during the second wave of the pandemic where new variants of the Coronavirus started to be found, once again wreaking havoc worldwide. The questionnaire asked about the impact of the pandemic on firms' performance, their coping strategies and their application of technology in their responses. A total of 106 responses were sent back, all of them were valid for analysis. The data was analyzed using Statistical Package for the Social Sciences (SPSS) version 25.0 for Windows (SPSS Inc., Chicago, IL, USA). Descriptive analysis was run to summarize the characteristics of respondent firms, then identify the responses of firms in coping with the pandemic and their technological application in operation.

\section{Results}

\section{A. Firm characteristics}

The survey was distributed to logistics companies in all regions but up to $77 \%$ of the respondents are from Northern of Vietnam, among which, the majority (64\%) is in Hanoi City. The most common business type recorded in this survey is Vietnamese firms, with up to $95 \%$, including state-owned and private companies. Regarding business size, $60 \%$ are small and medium businesses which have less than 200 employees, and $35 \%$ record a revenue of $150,000-2$ million
USD in 2020. Table 1 shows details of respondents by different categories.

\begin{tabular}{|c|c|c|}
\hline Characteristics & $\mathbf{n}$ & $\%$ \\
\hline \multicolumn{3}{|l|}{ Location } \\
\hline Hanoi City & 68 & 64.2 \\
\hline HCM City & 13 & 12.3 \\
\hline Northern Prov & 18 & 17.0 \\
\hline Middle Prov & 7 & 6.6 \\
\hline \multicolumn{3}{|l|}{ Business type } \\
\hline State-owned & 2 & 1.9 \\
\hline Vietnamese private & 94 & 88.7 \\
\hline FDI enterprise & 6 & 5.7 \\
\hline Business household & 4 & 3.8 \\
\hline \multicolumn{3}{|l|}{ Employee size } \\
\hline$<10$ employees & 19 & 17.9 \\
\hline 11-50 employees & 33 & 31.1 \\
\hline 51-200 employees & 31 & 29.2 \\
\hline$>200$ employees & 23 & 21.7 \\
\hline \multicolumn{3}{|l|}{ Revenue size } \\
\hline$<\$ 150 \mathrm{~K}$ & 24 & 22.6 \\
\hline$\$ 150 \mathrm{~K}-2 \mathrm{mil}$ & 37 & 34.9 \\
\hline$\$ 2$ mil-9mil & 26 & 24.5 \\
\hline \$9mil-50mil & 11 & 10.4 \\
\hline$>\$ 50 \mathrm{mil}$ & 8 & 7.5 \\
\hline Overall & 106 & 100.0 \\
\hline
\end{tabular}

The survey also asks about the types of services provided by logistics firms, and respondents can choose multiple options. Table 2 shows that road transportation, custom handling, and sea transportation are the most common services offered by respondent firms.

Table 2. SERvice offerings

\$Services Frequencies

\begin{tabular}{|c|c|c|c|c|}
\hline & & \multicolumn{2}{|c|}{$\underline{\text { Responses }}$} & \multirow{2}{*}{$\begin{array}{l}\text {-Percent } \\
\text { tof Cases }\end{array}$} \\
\hline & & $\mathrm{N}$ & Percent & \\
\hline \multirow[t]{11}{*}{ LogisticServices $^{\mathrm{a}}$} & Sea transport & 51 & $13.0 \%$ & $48.1 \%$ \\
\hline & Air transport & 43 & $11.0 \%$ & $40.6 \%$ \\
\hline & Railway transport & 17 & $4.3 \%$ & $16.0 \%$ \\
\hline & Road transport & 74 & $18.9 \%$ & $69.8 \%$ \\
\hline & Express delivery & 27 & $6.9 \%$ & $25.5 \%$ \\
\hline & Warehousing & 39 & $9.9 \%$ & $36.8 \%$ \\
\hline & Custom & 52 & $13.3 \%$ & $49.1 \%$ \\
\hline & Loading & 22 & $5.6 \%$ & $20.8 \%$ \\
\hline & Verification & 15 & $3.8 \%$ & $14.2 \%$ \\
\hline & Direct delivery & 21 & $5.4 \%$ & $19.8 \%$ \\
\hline & Others & 31 & $7.9 \%$ & $29.2 \%$ \\
\hline Total & & 392 & $100.0 \%$ & $0369.8 \%$ \\
\hline
\end{tabular}

a. Dichotomy group tabulated at value 1 .

\section{B. Impact of COVID-19 pandemic}

$82 \%$ of firms responded that their companies were negatively affected by the Coronavirus, $12 \%$ stated no impact, 
and only $5 \%$ recognized positive impact. Despite that, $62 \%$ of firms are still operating but project a declined performance. Up to $75 \%$ of surveyed companies estimate a decrease in revenue, $24 \%$ report either unchanged or increased revenues. Table 3 showed further details on how Vietnamese logistics companies are affected by the global pandemic.

Table 3. Impact of Covid-19 ON LOGISTICS FiRMS

\begin{tabular}{lcc}
\multicolumn{1}{c}{ COVID-19 impact } & n & \% \\
\hline \multicolumn{1}{c}{ General impact } & & \\
Positive impact & 6 & 5.7 \\
Negative impact & 87 & 82.1 \\
No impact & 13 & 12.3 \\
$\quad$ Disruption estimate & & \\
Within 2 weeks & 10 & 9.4 \\
Within 4 weeks & 3 & 2.8 \\
1-3 months & 7 & 6.6 \\
3-6 months & 2 & 1.9 \\
Unable to evaluate & 18 & 17.0 \\
Still operating & 66 & 62.3 \\
$\quad$ Projected revenue & & \\
Decrease $<25 \%$ & 25 & 23.6 \\
Decrease $25-50 \%$ & 37 & 34.9 \\
Decrease $>50 \%$ & 18 & 17.0 \\
Unchanged & 11 & 10.4 \\
Increase $<20 \%$ & 10 & 9.4 \\
Increase $>20 \%$ & 5 & 4.7 \\
$\quad$ Overall & 106 & 100.0 \\
\hline
\end{tabular}

Regarding the reasons for possible stop in operation, supply chain disruption accounts for around $12 \%$, and voluntary stop due to pandemic risks make up the largest proportion (Table 4). By location, government mandate affects logistics companies in Northern region (including Hanoi City) the most.

\section{Firm responses to the pandemic}

Firms have different ways to adapt to changes brought by the pandemic. Results in Table 5 showed that most firms adopt new ways of doing things (such as adapting to changes in clients' needs) (28\%), digitalize business activities $(26 \%)$, and other activities $(26 \%)$ in accordance with Covid-handling practices suggested by the government such as following safety mandate (mask-wearing, etc.) and educating employees about the pandemic.

TABLE 5. Firm RESPONSES to COVID-19

\$Response Frequencies

\begin{tabular}{|c|c|c|c|c|}
\hline & & \multicolumn{2}{|c|}{ Responses } & \multirow{2}{*}{$\begin{array}{l}\text { Percent of } \\
\text { Cases }\end{array}$} \\
\hline & & $\mathrm{N}$ & Percent & \\
\hline \multirow[t]{5}{*}{ CopingStrategies $^{\mathrm{a}}$} & New practices & 90 & $27.9 \%$ & $84.9 \%$ \\
\hline & Digitalization & 83 & $25.7 \%$ & $78.3 \%$ \\
\hline & Training & 21 & $6.5 \%$ & $19.8 \%$ \\
\hline & $\begin{array}{l}\text { Employee } \\
\text { Support }\end{array}$ & 43 & $13.3 \%$ & $40.6 \%$ \\
\hline & Covid response & 86 & $26.6 \%$ & $81.1 \%$ \\
\hline Total & & 323 & $100.0 \%$ & $304.7 \%$ \\
\hline
\end{tabular}

a. Dichotomy group tabulated at value 1 .

\section{Technological implementation}

Regarding the use of technology in business operation. $40 \%$ of firms have integrated technology in their business before the pandemic happened, 17\% started apply technology when the pandemic began, $22 \%$ are preparing to use, but there are still up to $20 \%$ of firms expressed no interest in

\begin{tabular}{|c|c|c|c|c|c|c|c|c|c|c|c|}
\hline & & \multicolumn{10}{|c|}{ Location } \\
\hline & & \multicolumn{2}{|c|}{ Hanoi City } & \multicolumn{2}{|c|}{ HCM City } & \multicolumn{2}{|c|}{ Northern Prov } & \multicolumn{2}{|c|}{ Middle Prov } & \multicolumn{2}{|c|}{ Row Total } \\
\hline & & \multirow[b]{2}{*}{ Count } & \multicolumn{2}{|l|}{ Row N } & \multicolumn{2}{|l|}{ Row N } & \multicolumn{2}{|l|}{ Row N } & \multicolumn{2}{|l|}{ Row N } & \multirow{2}{*}{$\begin{array}{c}\text { Row N } \\
\% \\
\end{array}$} \\
\hline & & & $\%$ & Count & $\%$ & Count & $\%$ & Count & $\%$ & Count & \\
\hline \multirow[t]{7}{*}{ Causes } & Voluntary stop & 8 & $44.4 \%$ & 2 & $11.1 \%$ & 2 & $11.1 \%$ & 6 & $33.3 \%$ & 18 & $100.0 \%$ \\
\hline & Contraction & 6 & $66.7 \%$ & 1 & $11.1 \%$ & 2 & $22.2 \%$ & 0 & $0.0 \%$ & 9 & $100.0 \%$ \\
\hline & Mandate & 3 & $75.0 \%$ & 0 & $0.0 \%$ & 1 & $25.0 \%$ & 0 & $0.0 \%$ & 4 & $100.0 \%$ \\
\hline & $\mathrm{SCM}$ & 8 & $61.5 \%$ & 2 & $15.4 \%$ & 2 & $15.4 \%$ & 1 & $7.7 \%$ & 13 & $100.0 \%$ \\
\hline & disruption & & & & & & & & & & \\
\hline & Still operating & 43 & $69.4 \%$ & 8 & $12.9 \%$ & 11 & $17.7 \%$ & 0 & $0.0 \%$ & 62 & $100.0 \%$ \\
\hline & Row Total & 68 & $64.2 \%$ & 13 & $12.3 \%$ & 18 & $17.0 \%$ & 7 & $6.6 \%$ & 106 & $100.0 \%$ \\
\hline
\end{tabular}


logistic technology at all. Table 5 below further shows the types of technology that firms believe that can help them to overcome obstacles caused by COVID-19. Generally, technologies that assist in order management activities (such as order management system, transport management system, delivery management system) are viewed as the most useful.

Table 6. Logistics Technologies

\$TechApplication Frequencies

\begin{tabular}{llrr}
\hline & \multicolumn{2}{c}{ Responses } & Percent of \\
\cline { 2 - 4 } Cases
\end{tabular}

a. Dichotomy group tabulated at value 1 .

\section{Discussion}

The prolonged pandemic has caused a negative impact on the majority of logistics firms, and very few firms benefiting from this event. This is confirmed with the findings in previous section, which shows that more than $80 \%$ of firms realize a negative impact from COVID-19 and 75\% record a loss. Firms of all sizes are affected negatively by the pandemic; however, closer inspection shows that micro and small businesses record much bigger loss compared to medium and big firms. In fact, a proportion of medium and large businesses even recognize an increase in revenues. Moreover, percentage of medium and large firms in operation during the pandemic is larger than the number of smaller firms. Notably, micro and small businesses seem more likely to be unable to evaluate how long their business operation is halted, which implies a big risk of failures. Medium and large businesses have the resources to withstand the difficulties; furthermore, results show that the more revenues the companies have, the more ready they are in terms of technological application, which further assists them in time of crises. All of the firms which realize an over-twenty-percent-increase in revenue during the pandemic reported that they had integrated technology in business activities long before. Even though quite many firms are either preparing to apply technology or having started technological application since the pandemic, there is still a significant proportion of small firms showing no intention of getting on this trend. Responses of logistics firms during the pandemic in Vietnam focuses on adapting to changes in customers' demand and to changes to virus-prevention prac- tices. It is also note-worthy that very few firms spent efforts on training employees in adaptation to changes in the workplace brought on by the pandemic, this would reduce the effectiveness of new practices when employees are not educated on how to.

\section{Conclusion}

Logistics firms in Vietnam are not well-prepared for turbulent environment, many act when the situation forces them to do so; and even then, some refuse to change the old ways of working. If businesses do not innovate to adapt to the environment, eventually, they will be driven out of the market. The paper brings attention to the need to invest in technology and human resources, both of which are crucial in helping the firms overcome obstacles. Despite the contribution to the underdeveloped literature on logistics of emerging countries and discussion of the currently soughtafter topics related to Coronavirus epidemic, the paper has a limitation of small population. Larger sample would be more helpful in exploring the interplay between firm characteristics, their coping strategies, and their effectiveness in response to crises.

As there is currently a lack of research on logistics firms in Vietnam, future work should investigate business nature of logistics firms in Vietnam, their performances as well as important aspects of their operation such as strategic management, human resource management, and logistics technology.

\section{REFERENCES}

[1] Apfalter, S., Hommes, M., Pereira Mendes, M., \& Toba, N. (2020). Lessons for electric utilities from COVID-19 responses in emerging markets. Retrieved from https://openknowledge.worldbank.org/ handle/10986/34854

[2] Baldwin, R., \& Freeman, R. (2020). Supply chain contagion waves: Thinking ahead on manufacturing 'contagion and reinfection' from the COVID concussion. https://voxeu.org/article/covid-concussionand-supply-chain-contagion-waves

[3] Baldwin, R., \& Weder di Mauro, B. (2020). Economics in the time of COVID-19. https://voxeu.org/article/economics-time-covid-19-newebook

[4] Bonadino, B., Huo, Z., Levchenko, A., \& Pandalai-Nayar, N. (2020, June). The role of supply chains in the COVID-19 pandemic and beyond. https://iap.unido.org/articles/role-global-supply-chains-covid19-pandemic-and-beyond

[5] Bui, B. N. (2020). Solutions and international experience in dealing with the Covid-19 pandemic in Logistics Activities and Vietnam's Border Trade. Proceedings of International Conference: The Impact of COVID-19 in Vietnam, pp 81-95.

[6] Dimakou, O., Romero, M. J., \& Van Waeyenberge, E. (2020). Never let a pandemic go to waste: Turbocharging the private sector for development at the World Bank. Canadian Journal of Development Studies/Revue Canadienne d'études Du Développement, 42(1-2), 221-237.

[7] Thilo Kroeger ; Anh Thi Ngoc Nguyen ; Yuanyan Sophia Zhang ; Pham Dinh Thuy ; Nguyen Huy Minh ; Duong Danh Tuan (2021). Corporate Vulnerabilities in Vietnam and Implications of COVID-19. IMF Working Paper. https://www.imf.org/en/Publications/WP/Issues/ 2020/11/20/Corporate-Vulnerabilities-in-Vietnam-and-Implicationsof-COVID-19-49893

[8] L'Hermitte, C., Tatham, P., \& Bowles, M. (2014). Classifying logistics-relevant disasters: Conceptual model and empirical illustration. Journal of Humanitarian Logistics and Supply Chain Management, 4(2), 155-178.

[9] Singh, S., Kumar, R., Panchal, R., \& Tiwari, M. K. (2021). Impact of COVID-19 on logistics systems and disruptions in food supply chain. International Journal of Production Research, 59(7), 19932008. https://doi.org/10.1080/00207543.2020.1792000 
[10] Tue My (2021). e-Logistics: Challenges for businesses to adopt technology (Doanh nghiep con gian nan de chuyen doi so) VNEconomy. Available at: https://vneconomy.vn/e-logistics-doanhnghiep-con-gian-nan-de-chuyen-doi-so.htm

[11] United Nations (2020). COVID-19 Socio-economic response plan for Vietnam. Available at: https://unsdg.un.org/sites/default/files/202010/VNM Socioeconomic-Response-Plan 2020.pdf

[12] UNCTAD (2021). Investment Trends Monitor. Issue 38. Available at: https://unctad.org/system/files/official-document/diaeiainf2021d1 en. pdf
[13] Vietnam Logistics Association (2021). Available at: https:// www.vla.com.vn/hiep-hoi-doanh-nghiep-dich-vu-logistics-15-doanhnghiep-mat-50-doanh-thu-50-doanh-nghiep-giam-manh-so-luongdich-vu-so-voi-cung-ky.html

[14] WTO (2021). How COVID-19 is changing the world: a statistical perspective - Volume III. Available at: https:/www.wto.org/english/ tratop_e/covid19_e/ccsa_publication_vol3 e.pdf 